\title{
The Metaphysics of Globalization in Heidegger
}

\begin{abstract}
By referring to Heidegger's understanding of metaphysics in his later philosophy, a fundamental relationship between the tradition of metaphysical thinking and the globalization of the principles of modernity may be considered. Both metaphysics and globalization share the same concept of world, which since the beginnings of modernity is understood as the accessibility of beings in their entirety. The principles of modernity-such as world-accessibility, quantification, energy-funding, accumulation and dominance-are grounded in a metaphysical understanding of the human condition that is characterized by the subject-object division. This metaphysical understanding of the man-world relationship is considered to be the deeper rationale of all essential phenomena of the modern age-such as philosophy, technology, natural science, economy, politics of power, and even humanism - which all tend to globalize their fundamental principles. Investigating the Heideggerian criticisms of metaphysics helps in understanding the deeper meaning of the notion of 'world', as this term is used in the discourse about globalization.
\end{abstract}

\section{Globalization and the concept of world}

\footnotetext{
Metaphysics is in all its forms and historical stages a unique but perhaps necessary, fate of the West and the presupposition of its planetary dominance. The will of that planetary dominance is now in turn affecting the center of the West. (Heidegger 1973, p. 90)
}

Here, Heidegger connects the planetary dominance of the western hemisphere (the globalization that originates from within Europe in the context of western imperialism and colonialism, but which became a connected systemic order and, therefore, turns back affecting its center) with a certain 'way of thinking'-'metaphysics'-that is meant to be the presupposition and deeper rationale of global modernity. What metaphysics and globalization do have in common is precisely this 'will to domination'. Metaphysics 'as philosophy' is a discourse about what is meta, 'over' the physis; the certain beings in the world, and about what is 'transcendent' to those beings (Heidegger 1998, p. 93). What goes beyond the certain 'beings in' the world was interpreted by the tradition

Marco Kleber, Technische Universität Dresden (TUD)

Ә OpenAccess. (C) 2018 Marco Kleber, published by De Gruyter. (cc) BY-NC-ND This work is licensed under the Creative Commons Attribution-NonCommercial-NoDerivatives 4.0 License. https://doi.org/10.1515/9783110492415-027 
of metaphysical thinking as 'the world itself'-the 'totality' of all beings. "'World' serves, here, as a name for beings in their entirety." (Heidegger 2002, p. 67) Since its beginnings in ancient philosophy, metaphysics has given thought to this totality called 'world', and, by doing so, attempted to subordinate the totality of beings to this thinking, to make it accessible to human thought. Otherwise, metaphysics would not have been able to think about beings in their entirety, and, if so, there would be no metaphysical philosophy at all. It is indeed of necessity to the logic of thought to refer to this entireness, and, therefore, metaphysics became the 'fate' of the west. Though, thinking of the world as a whole at first leads to 'dominating' it. Thereby, the same problematic reference to the totality of all beings is inherent both to metaphysics and to globalization: the world as a whole is affected by globalization and needs to be made available and connected within the ongoing process of globalization.

Metaphysics and globalization do indeed have the same will to domination, because they both share the same concept of 'world': as a totality that is accessible to human will and thinking. The notion of world, precisely as this term is used in contemporary discourse about globalization (world society, world market, world trade, world bank, world system, world order, world currency, world war, world fair, world citizenship, worldwide networking and orientation) is actually a metaphysical concept; it originates from the history of metaphysical

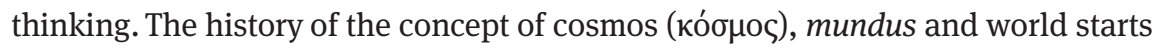
with Pre-Socratic philosophy (like Heraclitus) and can be retraced through the Gospel of John and in Christian philosophy (Augustine, Thomas Aquinas) to modern times (Kant) and, from its beginnings, shows certain kinds of ambivalences (Heidegger 1998, pp. 111-121). These ambivalences also concern the globalized principles of modernity. Modernity always tends to totalize the will to make the world accessible: to expand towards all spots of the globe (including the seabed), towards interplanetary space, as well as into the inner cores of atoms and the biological micro-structures of life, and towards all aspects of human society.

\section{Phenomena of the age}

Modern metaphysics, according to Heidegger, is based in the philosophical principle of subjectivity and, therefore, is characterized by radical subject-object division. The fact that man is now philosophically interpreted as a subject (from the Latin subiacere, which means 'to lie below') says that he now understands his own existence and reasoning as the instance in which all beings are grounded: 
The word names that-which-lies-before, that which, as ground, gathers everything onto itself. This metaphysical meaning of the concept of the subject has, in the first instance, no special relationship to man, and none at all to the I. (Heidegger 2002, p. 66)

Therefore, to understand oneself as a subject means to realize a specific relationship to the world of beings: for those, 'to be' now means to be an object that may be represented and known by the subject. All beings are (and the world is) now defined by the principle of subjectivity and its corresponding principle of objectification. "Beings as a whole are now taken in such a way that a being is first and only in being insofar as it is set in place by representing-producing [vorstellend-herstellenden] humanity." (Heidegger 2002, pp. 67-68) Because the world is now defined by its capability of being representable by the subject, and as far as a 'representation' is synonymous with a 'picture', Heidegger can re-name modernity as The Age of the World Picture, which is the title of his famous essay from 1938 (Heidegger 2002, p. 57).

This essence of modernity-that all beings exist as representable objectivity and that the world itself is understood as such a representation-is the 'ground' of all so-called 'essential phenomena' of the age. That means, with regard to all those basic "phenomena [Erscheinungen], their metaphysical ground must allow itself to be recognized in them" (Heidegger 2002, p. 57). This recognition of the phenomena must be the only argument to justify the assumption of a metaphysical ground of an age, or, of modernity being the age of the world picture. What are, according to Heidegger, these essential phenomena of modernity?

Firstly, there is metaphysics itself, as the philosophy of the $17^{\text {th }}$ to up to the $20^{\text {th }}$ century. It is precisely "the guiding thought of modern philosophy" that "something 'is' only insofar as a founded cognition has secured it for itself as its object.” (Heidegger 1991, p. 27) This can be found in Heidegger's Interpretation of Leibniz's principium rationis - the principle of sufficient reason-that is essential to early-modern philosophy and which says that "Nothing is without reason. The principle now says that every thing counts as existing when and only when it has been securely established as a calculable object for cognition." (Heidegger 1991, p. 120) To say that everything exists only with reason, and nothing without reason, implies that everything, every being is accessible to human cognition (as the criteria of this being), which can always represent the reason why this being exists. Metaphysics, which, throughout its history, more and more tended to interpret 'being' at all as 'being an object', is understood by Heidegger as the effect of an 'erroneous trend' within western culture, with global modernity as its final manifestation. Its preconditions go back to Parmenides and his famous assessment "that, namely the same, is perceiving as well as being" (Heidegger 1991, p. 73), but this seed sprouted only when it was "in the 
metaphysics of Descartes that, for the first time, the being is defined as the abjectness of representation, and truth as the certainty of representation" (Heidegger 2002, p. 66). Heidegger even includes his own philosophy of his earlier writings into his criticism of objectivizing metaphysical thoughts, when he, in 1929, implicitly argues against his first major work Being and Time from 1927. This approach, by mistake, identified the ontological context of object-usage with the phenomena of the world (cp. Heidegger 1998, pp. 121, 370, footnote 52).

Secondly: Because of metaphysics defining 'world' as the totality of beings, which is 'accessible' to human thought, modern technology is the most consistent realization and materialization of the essence of metaphysical thinking (Luckner 2008, pp. 59, 93). What distinguishes 'modern' from 'traditional' technology-for example, a hydroelectric power plant from a traditional watermill -is that the mill indeed uses the water flow of the river, but that the power plant represents the idea of 'whole' nature being an accessible resource for the demand of accumulating energy. Modern technology, like the power plant, "puts to nature the unreasonable demand that it suppl[ies] energy that can be extracted and stored as such.” (Heidegger 1977, p. 14) Unlike the movement of the mill that is built into the river, energy is-like money-an abstract category that can, in principle, be accumulated infinitely (Luckner 2008, p. 114). 'Whole' nature, then, becomes primarily a resource for technology. Thus, modern technology is, indeed, not essentially defined as a useful means to an end, but as a (metaphysically determined) conception of what nature in its entirety is.

Thirdly: Insofar as modern 'natural science' understands nature in its entirety as a calculable coherence of forces and energies (which can be anticipated by referring to natural law and made controllable by experiments using measurement and mathematical calculation as its basic methods) it totally complies with the essence of modern technology (Heidegger 2002, pp. 61-66; 1977, p. 21). By referring to 'nature' as quantifiable, mathematized and, therefore, secured to human disposal, the world of natural sciences is nothing other than the entireness of potential technological (and economic) resources. If anything cannot be represented and imagined as a calculable coherence of forces and, thus, cannot become open to technological and/or economical access, it is not at all 'nature' in the sense of modern 'natural' science.

Fourthly: Heidegger addresses the 'economy' as an essential phenomenon of the modern age in the context of his reception of Marx and Hegel. He points out that Marx's concept of 'dialectical materialism' "does not consist in the assertion that everything is simply matter but rather in a metaphysical determination according to which every being appears as the material of labor" (Heidegger 1998, p. 259). The metaphysical background of labor was, before Marx, first thought in "Hegel's Phenomenology of Spirit as the self-establishing process of un- 
conditioned production, which is the objectification of the actual through the human being, experienced as subjectivity" (Heidegger 2008, p. 295). Every being-the whole metaphysical world-appears as the material of labor, which transforms natural being into technology and, by this, labor produces the added-value which is needed for the self-establishing process of capital accumulation in modern societies. Capitalism is exactly that kind of economic system that can at its best execute the metaphysical objectification of world and the essence of technology.

Fifthly: The metaphysical trinity of technology, science and economy effectuates that politics have to give rise to the claim to make the world accessible to objectification and technological access. Thereby, politics transforms itself into 'politics of power' and, from a global perspective, into 'geopolitics'. The political leaders of nation states, inside and outside, have to push forward mechanization and technological progress, which causes the clash of nations and leads, according to Heidegger, to geopolitical conflicts, including the world wars (Vietta 2015, p. 163). The newly-published Black Notebooks by Heidegger deal, among other things, with the global political power blocks after World War II-the Soviet Union and the United States-which seem to have oppositional political ideologies, but are indeed driven by the same concept of power (Heidegger 2014, p. 173-174; Vietta 2015, p. 164).

The struggle between those who are in power and those who want to come to power: On every side there is the struggle for power. [...] This struggle is of necessity planetary and as such undecidable in its being because it has nothing to decide [...]. (Heidegger 1973, p. 102)

There is a thinking related to spheres of influence and global supremacy in geopolitical situations, driven by technological and economical constraints, in which this planetary struggle, with power being an end in itself and its object being the entire world, has not necessarily anything to decide, because the categories of power itself and its 'understanding' of the world as accessible to men -the 'metaphysical' approach of technology and economy-is never questioned as such.

Sixthly: The aforementioned aspects and consequences of metaphysical thinking about the world ultimately result from the self-understanding of man as a subject and, therefore, relate to humanism and its anthropology. Humanism intends to moralize man and, with this, to let him recognize his own dignity. Indeed, all variants of humanism "presupposed the most universal 'essence' of the human being to be obvious. The human being is considered to be an animal rationale.” (Heidegger 1998, p. 245) Regarding this definition, the subject-object 
distinction is repeated and duplicated within the human being itself. Man is 'animal', i.e. a living creature understood as a biological organism; in addition to this, man is rationale, with the ability to be rational and reasoning. In the formula man = organism + rationality, 'human being' divides itself into being a subject and being an object. Human existence itself is now understood as being-an-object to a subject and enters the realm of accessibility to the metaphysical subjectivity. Man himself becomes a resource on behalf of technology: "Man, who no longer conceals his character of being the most important raw material, is also drawn into this process." (Heidegger 1973, p. 104) With this being an implication of the humanist understanding of man, the basic ideas of humanism, such as freedom and human dignity, are (not in an unproblematic way) simply oppositional to the exploitation or even self-exploration of humans. Heidegger relates these negative dialectics of humanism to the idea of the absolute value, which is regarded as human dignity:

Rather, it is important finally to realize that precisely through the characterization of something as 'a value' what is so valued is robbed of its worth. That is to say, by the assessment of something as a value what is valued is admitted only as an object for human estimation. [...] Every valuing, even where it values positively, is a subjectivizing. It does not let beings: be.” (Heidegger 1998, p. 265)

The paradox of human dignity is that, by attributing an absolute value to himself, man attributes to himself and transforms himself into an object that is relative to this attribution, and, therefore, does not seem to relate to himself anymore as absolute. On the contrary, this does not mean that it is possible to deny human dignity, but rather that "Humanism is opposed because it does not set the humanitas of the human being high enough" (Heidegger 1998, p. 251). Furthermore, this means that we have to think about the essence of human dignity in a new and more radical way, by considering the negative aspects that the ideas of humanism may have.

These abovementioned aspects of the phenomena of the age-modern philosophy, technology, science, economy, politics of power and humanism-are related to metaphysics, because metaphysics refers to the world of beings in their entirety, or to nature-and because this entireness is also addressed within the phenomena that are essentially defined as concepts about what 'being' or 'world' actually means. Heidegger's basic intention is to fulfill the so-called 'Turning' (Heidegger 1977, p. 36), which means to think both of beings in their entirety and of the relation of human existence to this entireness in a new way: to think the "transition from metaphysics to the thinking of being in its historicality" (Heidegger 2012, p. 5). At first, this means to consider that the phenomena of an age are grounded in a deeper understanding of the world. Be- 
cause, concerning the age of modernity, an understanding of the world as 'accessible' to man appears as essential to all phenomena of modernity, modernity as such tends to globalize its principles, such as power, quantification, mathematization, technologization and energy production. The metaphysical concept of the world is indeed inherent to modernity. The age of the 'world picture' is the age of globalization.

\section{Two concepts of world: the universe and the globalization}

According to the humanistic definition of man-which, according to Heidegger, is 'not false' but 'conditioned by metaphysics' (Heidegger 1998, p. 246)-the human being is an animal rationale; a definition that appears within ancient and medieval philosophy as the Latin translation of the Grecian zoon logon

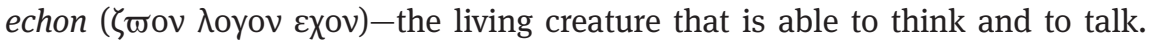
To be rational means to be able to have thoughts, and this implies the ability to form sentences and phrases, or, to use language. One of the most fundamental logical principles of language is predication: the possibility to say that any being is another determination, like, for example, a 'quality' of this being. What does this 'is' mean? In contrast to the 'certain' being in the world (which is defined by a summary of its actual or possible determinations and can be separated and distinguished from other beings), the 'is'-which appears within human language and, by this, must be meaningful-has no certain qualities. That the being is, must be something else than how and what it is.

This is what Heidegger calls the 'ontological difference': the distinction between "beings in their being, and being of beings" (Heidegger 1998, p. 105). Because man can understand 'is' or 'to be' within the usage of language, the 'being of all' beings is related to his existence. And because this 'being' does not mean something special-no particular fact or thing in the world-but that being is, human existence is not limited to certain areas of beings, but has an essential relationship to the entireness of beings, to the world. Indeed, this world is not an object to a human subject, like 'certain' beings could be objectivized. This marks the erroneous trend both within the tradition of metaphysical thinking, and the cultural history that leads to the principles of modernity-to the age of the 'world picture'-that always tends to subordinate the entireness of beings to an object of calculation and disposal. But the turning to a different way of thinking concerning the world can be made throughout the metaphysical definitions. To Heidegger, human being (Dasein) now stands in a relationship to world 
that is defined as the 'transcendence' to certain beings: "We name world that toward which Dasein as such transcends, and shall now determine transcendence as being-in-the-world." (Heidegger 1998, p. 109) As the hyphens in Heidegger's new phrase indicate, 'being-in-the-world' is meant to be a structure in which there is a fundamental unity concerning the relationship between human existence (which is called Dasein) and being of beings, called world. The emphasis of this unity avoids the subject-object division of early modern philosophy up to the $20^{\text {th }}$ century, which complies with the problematic principles of modernity as such. Again: what is the problem concerning the modern understanding of 'world'?

Heidegger explains why there always appears a problem when the essential human-world relationship-the 'being-in-the-world'-is divided into subject and object, or, equally, when the unity of the world is 'abstracted' atwain:

\footnotetext{
It is therefore equally erroneous to appeal to the expression world either as a designation for the totality of natural things (the natural concept of world), or as a term for the community of human beings (the personal concept of world). Rather, what is metaphysically [52] essential in

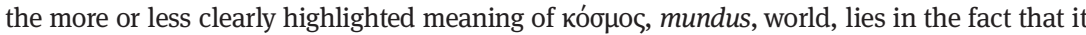
is directed toward an interpretation of human existence [Dasein] in its relation to beings as a whole. [...] World belongs to a relational structure distinctive of Dasein as such, a structure that we called being-in-the-world. (Heidegger 1998, pp. 120-121)
}

The fundamental man-world relationship is undermined by subject-object division, and by the understanding of world as representational. This leads to an understanding of 'world' in which there are actually two totally different usages of the notion: the natural concept of world and the personal concept of world. The two are equally erroneous - the former as a designation of the totality of all natural objects (without the human subject), and the latter as a name for the community of human beings (to which nature is accessible).

We can recognize these two usages of the notion of 'world' in the discourse about modernity and globalization. Modernity, firstly, describes the 'natural' world in its entirety, including its most distant phenomena, which can only be visualized due to the invention of the astronomic telescope, and which are meant to be explained by referring to the basic principles concerning the behavior of matter. This understanding of the world is named the 'universe'. In this so-called universe there is nothing like the phenomena of humanity. The universe is not the human world. Human existence-Heidegger's Dasein-is not a relevant object to those sciences that have the authority to define the concept of the universe.

In his book Mind and Cosmos, Thomas Nagel points out that the "great advances in the physical and biological sciences were made possible by excluding the mind from the physical world. This has permitted a quantitative understand- 
ing of that world, expressed in timeless, mathematically formulated physical laws." (Nagel 2012, p. 8) The main thesis of his book is that this leads to an aporia, "since mind is the product of a partly physical progress"-even the mind of the scientist who works with the theory-but these physical sciences "have been developed for a mindless universe" (Nagel 2012, p. 12). Opposing the supreme paradigms of Neo-Darwinism and materialism, and for the sake of the future development of our scientific culture and theory, the question should be asked of how a more comprehensive understanding of the physical reality, which includes the mind (phenomena such as consciousness, cognition, value, conclusion), might be possible (cp. Nagel 2012). It could be true that it is the most important characteristic of matter or of the physical universe that it can bring mind into reality and that matter should be re-thought in categories of the mind.

While the paradigms of modern natural science are only made possible by excluding fundamental aspects of existence and life from these sciences, the human self-understanding is always implicitly in the background. The universe that is defined as pure objectivity is determined by man who, since the beginnings of modernity, exists as a subject. The 'natural' world is defined as the entireness of the behavior of pure matter. This is the metaphysical world, accessible to human disposal. The universe, a concept that 'underdetermines' human being in the world by excluding the principle of subjectivity, is actually linked to an 'overdetermination' of the human will within the modern understanding of 'world'. Then, man suddenly stands above all other natural things, which are reduced to their capacity to be objectivized and manipulated as energy resource, as experiment, and as commodity. This is expressed by a different usage of the notion of world: the world that is connected and made accessible by or within the world society, the world market, the world trade, the world bank, the world system, the world order, the world currency, the world wide web, etc. This concept of 'world', which defines it as the summary of all human involvements, is the world-concept of globalization, which is without doubt present in all current discourses about what globalization might be.

While the 'natural' concept of world excludes human activities and relationships from its definition of the universe, the second concept of world, by contrast, excludes nature from what is meant to be the world. However, this is so only if 'nature' is understood in the old, Aristotelian way-as that which is in-accessible to human disposal and manipulation, because it exists and moves on its own, a concept which is remarkably different to the understanding of 'nature' as a resource for energy production and economic growths (cp. Luckner 2008, pp. 103-104). With this, the two concepts of world are obviously linked; they result from the same abstractness that divides the essential relation and openness 
of human existence to the cosmos-a relational structure that is named being-inthe-world by Heidegger - into a pure object-side and a pure subject-side.

Globalization's understanding of the world arises during the beginning of European modernity with the exploration of North America, the decentralization of the globe in the Copernican revolution, the development of the central perspective within art, and the Cartesian philosophy. All these events have in common that the world (which is quite often imagined as the planetary globe) is objectivized by an external perspective. Since this, globalization expands towards all areas of the natural world, including man's own bodily nature and life, tending to make this world accessible. This process of globalization is understood by Heidegger as the quantification of the world, which can be seen in the "destruction of great distances by the airplane, in the representations of foreign and remote worlds in their everydayness produced at will by the flick of a switch" (Heidegger 2002, p. 71).

As shown, global modernity and metaphysics share the same concept of world. With this, metaphysics is the necessary presupposition of the planetary dominance of the West (the globalization of the European principles of world-accessibility) and the rise of a connected systemic order that in turn affects the center of the West.

\section{Bibliography}

Heidegger, Martin (1973): The End of Philosophy. Translated and introduction by Joan Stambaugh, New York: Harper and Row.

Heidegger, Martin (1977): The Question Concerning Technology and Other Essays. Translated by William Lovitt, NewYork: Harper \& Row.

Heidegger, Martin (1991): The Principle of Reason. Translated by Reginald Lilly, Bloomington, Indiana: University Press.

Heidegger, Martin (1998): Pathmarks. Edited by William McNeill, Cambridge: University Press. Heidegger, Martin (2002): Off The Beaten Track. Edited and Translated by Julian Young and Kenneth Haynes, Cambridge: University Press.

Heidegger, Martin (2012): Contributions to Philosophy (Of the Event). Translated by Richard Rojcewicz and Daniela Vallega-Neu, Bloomington, Indiana: University Press.

Heidegger, Martin (2014): Überlegungen XII-XV: Schwarze Hefte 1939-1941, Gesamtausgabe Vol. 96. Edited by Peter Trawny, Frankfurt am Main: Vittorio Klostermann.

Luckner, Andreas (2008): Heidegger und das Denken der Technik. Bielefeld: Transcript.

Nagel, Thomas (2012): Mind and Cosmos. Why the Materialist Neo-Darwinian Conception of Nature is Almost Certainly False. Oxford: University Press.

Vietta, Silvio (2015): “Etwas rast um den Erdball...”. Martin Heidegger: Ambivalente Existenz und Globalisierungskritik. Paderborn: Wilhelm Fink. 